June 2002

\title{
The autoregulatory role of EsaR, a quorum-sensing regulator in Pantoea stewartii ssp. stewartii: evidence for a repressor function.
}

Timothy D. Minogue

University of Connecticut, Storrs CT

Markus Wehland-von Trebra

Frei Universität Berlin, Berlin Germany

Frank Bernhard

Frei Universität Berlin, Berlin Germany

Susanne B. von Bodman

University of Connecticut, susanne.vonbodman@uconn.edu

Follow this and additional works at: https://opencommons.uconn.edu/plsc_articles

\section{Recommended Citation}

Minogue, Timothy D.; Wehland-von Trebra, Markus; Bernhard, Frank; and von Bodman, Susanne B., "The autoregulatory role of EsaR, a quorum-sensing regulator in Pantoea stewartii ssp. stewartii: evidence for a repressor function." (2002). Plant Science Articles. 19.

https://opencommons.uconn.edu/plsc_articles/19 


\section{The autoregulatory role of EsaR, a quorum-sensing regulator in Pantoea stewartii ssp. stewartii: evidence for a repressor function}

Timothy D. Minogue, ${ }^{1 *}$ Markus Wehland-von

Trebra, ${ }^{2 \dagger}$ Frank Bernhard ${ }^{2 \ddagger}$ and

Susanne B. von Bodman ${ }^{1,3}$

${ }^{1}$ Department of Plant Science University of Connecticut, 302B AG Biotech, Storrs, CT 06269, USA.

${ }^{2}$ Institut für Kristallographie, Freie Universität Berlin, D-14195 Berlin, Germany.

${ }^{3}$ Department of Molecular and Cell Biology, University of Connecticut, Storrs, CT 06269, USA.

\section{Summary}

Capsular polysaccharide synthesis and virulence in the plant pathogenic bacterium Pantoea stewartii ssp. stewartii requires the quorum-sensing regulatory proteins, EsaR and Esal, and the diffusible inducer $\mathrm{N}$-(3-oxo-hexanoyl)-L-homoserine lactone. Prior mutational studies suggested that EsaR might function as a repressor of quorum sensing in the control of capsular polysaccharide synthesis. Further, a lux box-like palindromic sequence coinciding with the putative -10 element of the esa $R$ promoter suggested a possible negative autoregulatory role for EsaR. This report presents genetic evidence that EsaR represses the esaR gene under inducer-limiting conditions, and that addition of inducer promotes rapid, dosedependent derepression. DNA mobility-shift assays and analyses by surface plasmon resonance refractometry show that EsaR binds target DNAs in a ligand-free state, and that inducer alters the binding characteristics of EsaR. Physical measurements indicate that the EsaR protein binds $\mathrm{N}$-(3-oxo-hexanoyl)L-homoserine lactone, in a 1:1 protein:ligand ratio, and that inducer binding enhances the thermal stability of the EsaR protein. These combined genetic and biochemical data establish that EsaR regulates its own expression by signal-independent repression and signal-dependent derepression. Additionally, we provide evidence that EsaR does not govern the

Accepted 18 March, 2002. *For correspondence. E-mail svbodman@ canr.uconn.edu; Tel. (+1) 860486 4408; Fax (+1) 8604860534. Present addresses: 'Institut für Klinische Pharmakologie und Toxikologie, Berlin, Germany. ‡Universität Frankfurt, Biozentrum, Institut für Biophysikalische Chemie, Marie-Curie-Str. 9, D-69439 Frankfurt/Main, Germany. expression of the linked esal gene, thus EsaR has no role in controlling coinducer synthesis.

\section{Introduction}

Bacteria express selected gene systems in a populationdependent manner by sensing self-produced, membranediffusible signals in a strategy called quorum sensing (QS) (Fuqua et al., 1996). The key elements of QS regulation in many Gram-negative bacteria are homologue proteins of Luxl, a $\mathrm{N}$-acyl-homoserinelactone (AHL) signal synthase, and LuxR, an AHL-dependent response regulator. These two proteins control the expression of bioluminescence in the marine bacterium, Vibrio fischeri (Fuqua et al., 1994; Williams et al., 2000; Fuqua et al., 2001; Miller and Bassler, 2001; Withers et al., 2001). Alternative QS mechanisms, mediated by unrelated control factors, exist in other Gram-negative bacteria, most notably Vibrio harveyi (Bassler et al., 1994), and in several Grampositive organisms (Dunny and Leonard, 1997; Kleerebezem and Quadri, 2001). In general, QS governs the control of diverse phenotypes, each benefiting a bacterium in a specialized habitat (Whiteley et al., 1999; Pierson, 2000; Whitehead et al., 2001).

Pantoea stewartii ssp. stewartii ( $P$. stewartii) is the causative agent of Stewart's wilt disease in sweetcorn and leaf blight in maize. Disease symptoms develop when the bacterium produces large amounts of a capsular polysaccharide (CPS), which blocks the corn xylem vessels and induces necrotic lesions (Coplin et al., 1992). CPS synthesis is a QS-controlled phenotype governed by the Luxl and LuxR homologue proteins, Esal and EsaR (von Bodman and Farrand, 1995). Disruption of the signal synthase gene, esal, leads to parallel loss of AHL, CPS production, and virulence. In contrast, mutations in the esaR gene give a hypermucoid phenotype irrespective of $\mathrm{AHL}$ (von Bodman et al., 1998). The simplest explanation for these observations is that EsaR functions as a repressor of CPS synthesis and that derepression requires inducing levels of AHL. The functions required for CPS synthesis are encoded by an extensive cps gene system (Dolph et al., 1988). This gene system is closely related to the wza gene cluster encoding the synthesis of the group I capsules, colanic acid in Escherichia coli (Reeves et al., 1996), and amylovoran in Erwinia 
amylovora (Bernhard et al., 1993). It is well established that these gene systems require transcriptional activation by the environmental response regulatory complex, RcsA/B (Gottesman and Stout, 1991; Kelm et al., 1997; Wehland et al., 1999). The difference in P. stewartii is that the level of RcsA/B-mediated control of stewartan synthesis is secondary to the dominant control by EsaR.

The controlled expression of the QS regulatory elements themselves is generally an integral feature of QS regulation (Shadel and Baldwin, 1992; Fuqua et al., 1994; Pesci et al., 1997; Whitehead et al., 2001). Thus, the strategy by which EsaR governs its own expression, and the expression of the linked esal gene, may be indicative of its role as a repressor of CPS synthesis. Preliminary observations suggested that EsaR regulates its own expression by repression (von Bodman and Farrand, 1995), although the role of the AHL signal in this mode of regulation was unclear. The current study focuses on a well conserved lux box-like sequence, the esaR box associated with the esaR gene, to explore whether EsaR protein is genetically and biochemically programmed for a role as a repressor of $\mathrm{QS}$.

\section{Results}

\section{Autorepression of the esaR promoter by EsaR}

LuxR, TraR and related QS transcription factors regulate their own expression by activation (Shadel and Baldwin, 1992; Hwang et al., 1994; Seed et al., 1995; Fuqua et al., 1996; Fuqua and Winans, 1996; Fuqua et al., 2001). The linked esal/esaR gene system of $P$. stewartii is convergently organized and features $3^{\prime}$ terminal ends that overlap by 21 basepairs (bp) (von Bodman and Farrand, 1995). The promoter of the esaR gene, not the esal gene, bears a defined esa $R$ box. This palindrome coincides with the putative -10 promoter sequence, which suggests that binding of EsaR at this site may block transcription and provide a mechanism for EsaR-mediated autorepression. To test this prediction, we developed an in vivo assay based on the coexpression of plasmids pTDM6 and pTDM7 in the E. coli Top 10 host strain, TM67 (Table 1). In this assay, plasmid pTDM6 (Fig. 1A) contributes the esaR coding sequence expressed from the $E$. coli $\mathrm{P}_{\mathrm{BAD}}$ promoter, which is controlled by the AraC regulator, also encoded on the plasmid, as a function of L-arabinose induction (Guzman et al., 1995). Plasmid pTDM7 carries an esaR::lacZY reporter gene fusion designed to measure the in vivo activity of the esaR promoter (Fig. 1A). Growth of strain TM67 in glucose-supplemented medium lacking L-arabinose yielded fully induced levels of $\beta$ galactosidase, whereas growth in the presence of $0.02 \%$ L-arabinose gave nearly 10 -fold lower levels of $\beta$-galactosidase (Fig. 1B). Intermediary levels of reporter activity were inversely proportional to the amount of L-arabinose provided. These data confirm that EsaR acts as a repressor, and that this repression is AHL-independent.

\section{Derepression is $A H L$ ligand-dependent}

Proof for EsaR mediating QS through a repression

Table 1. Strains and plasmids.

\begin{tabular}{|c|c|c|}
\hline & Relevant genotype & Reference or source \\
\hline \multicolumn{3}{|l|}{ Strain } \\
\hline TB1 & E. coli, JM83 hsdR (rk-mk+), $\Delta a r a$ & New England Biolabs \\
\hline $\mathrm{Top}_{10}$ & E. coli, lacZ $\Delta \mathrm{M} 15 \Delta$ lacX74 araD139 $\Delta$ (ara-leu) 7697 & Invitrogen \\
\hline $\mathrm{DH} 5 \alpha$ & E. coli, lacZAM15 $\Delta$ (lacZYA-argF)U169 gyrA96 & Invitrogen \\
\hline TM6 & E. coli $\mathrm{Top}_{10}(\mathrm{pTDM6})$ & This study \\
\hline TM67 & E. coli Top 10 (pTDM6, pTDM7) & This study \\
\hline TDM619 & E. coli Top $_{10}$ (pTDM6, pTDM19) & This study \\
\hline DC283 & P. stewartii, SS104, $\mathrm{Nal}^{\mathrm{R}}$ & Dolph et al. (1988) \\
\hline ESN51 & P. stewartii, esal::Tn5 & von Bodman and Farrand (1995) \\
\hline $\mathrm{ES} \Delta \mathrm{IR}$ & P. stewartii, $\Delta$ esal-esaR & von Bodman and Farrand (1995) \\
\hline \multicolumn{3}{|l|}{ Plasmids } \\
\hline pBluescript-II KS+ & Cloning vector, ColE1 ori, $\mathrm{Ap}^{\mathrm{R}}$ & Stratagene \\
\hline pBAD22 & Arabinose inducible expression vector, $A p^{R}$ & Guzman et al. (1995) \\
\hline pBBR1MCS-3 & Broad range expression vector, $\mathrm{Tc}^{\mathrm{R}}$ & Kovach et al. (1995) \\
\hline pSVB5-18 & esal and esaR cloned pBluescript-II KS+, $\mathrm{Ap}^{\mathrm{R}}$ & von Bodman and Farrand (1995) \\
\hline pLKC480 & Source of lacZY- $\mathrm{Km}^{\mathrm{R}}$ cassette & Tiedeman and Smith, 1988) \\
\hline pLKC481 & Source of lacZY-Km $\mathrm{Km}^{\mathrm{R}}$ cassette & Tiedeman and Smith (1988) \\
\hline pSVB60 & $\begin{array}{l}\text { esaR re-cloned from pSVB5-18 into pBBR1MCS-3 as a } \\
\text { Pstl-Sall fragment }\end{array}$ & This study \\
\hline pTDM6 & $\begin{array}{l}\text { PCR-amplified esaR coding sequence cloned into pBAD22as } \\
\text { a Ncol-Hindlll fragment }\end{array}$ & This study \\
\hline pTDM7 & esaR::lacZY-Km $\mathrm{Km}^{\mathrm{R}}$ gene fusion in pSVB60 & This study \\
\hline pTDM18 & $\begin{array}{l}\text { PCR-amplified esal promoter and partial coding sequence } \\
\text { cloned into pBBR1MCS-3 as a Xbal-Xmal fragment }\end{array}$ & This study \\
\hline pTDM19 & esal:: lacZY-Km $\mathrm{Km}^{\mathrm{R}}$ gene fusion cloned into the Xmal site of pTDM18 & This study \\
\hline
\end{tabular}


A
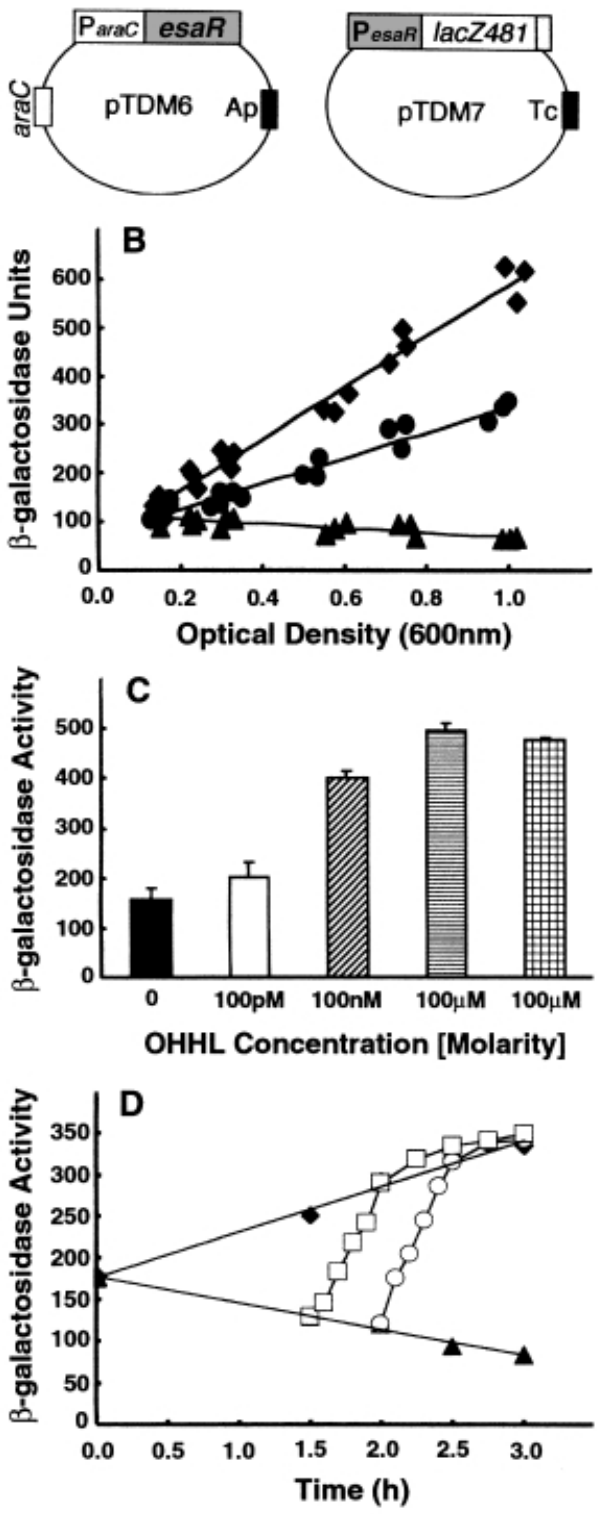

Fig. 1. Dose-dependent repression and derepression of an esaR translational fusion. The E. coli strain TM67 harbouring (A) plasmids pTDM6 and pTDM7 was grown (B) to different optical densities $(600 \mathrm{~nm})$ in the presence of $0 \%(\bullet), 0.0002 \%(\bullet)$, or $0.02 \%(\mathbf{\Delta})$ L-arabinose; or $(\mathrm{C})$ to an optical density $(600 \mathrm{~nm})$ of 0.6 in presence of $0.02 \%$ L-arabinose with $0(\square), 100 \mathrm{pM}(\square) 100 \mathrm{nM}$ (浔), $100 \mu \mathrm{M}$ (目) $\mathrm{N}$-(3-oxo-hexanoyl)-L-homoserine lactone (OHHL), or $0 \% \mathrm{~L}$-arabinose and $100 \mu \mathrm{M} \mathrm{OHHL}$ (曲).

D. Strain TM67 was grown with $0 \%(\bullet)$ or $0.02 \%$ L-arabinose $(\boldsymbol{\Delta})$ and harvested at different times after L-arabinose induction. Parallel cultures were treated with $100 \mu \mathrm{M} \mathrm{OHHL}$ at $1.5 \mathrm{~h}(\square)$ or $2 \mathrm{~h}(\bigcirc)$. The cells were harvested and assayed for $\beta$-galactosidase expressed as units (Sambrook et al., 1989) (B) or activity (Miller, 1972) (C and D).

mechanism would require evidence for inducing levels of the biologically relevant $\mathrm{AHL}$ signal, $\mathrm{N}$-(3-oxo-hexanoyl)L-homoserine lactone $(\mathrm{OHHL})$, to promote derepression. Accordingly, we grew strain TM67 under stringent repressive conditions in presence of $0.02 \%$ L-arabinose. Parallel cultures were supplemented with levels of synthetic $\mathrm{OHHL}$ ranging from $0 \mu \mathrm{M}$ to $100 \mu \mathrm{M}$. Derepression of the reporter function correlated directly to the quantity of OHHL supplied (Fig. 1C). More importantly, derepression occurred almost immediately upon addition of the OHHL (Fig. 1D). We conclude from these data that EsaR repression of its own gene is abolished by $\mathrm{AHL}$.

\section{EsaR does not control the expression of the esal gene}

We reported previously that $P$. stewartii strains mutated in the esaR locus synthesise wild-type levels of AHL (von Bodman and Farrand, 1995) suggesting that EsaR does not control the expression of the linked esal gene. We confirmed this observation by measuring levels of $\beta$-galactosidase expressed from an esal::lacZY translational gene fusion carried on plasmid pTDM19. When coexpressed with plasmid pTDM6 in E. coli strain TM619, this gene fusion produced identical levels of $\beta$-galactosidase regardless of whether or not the strain was induced with L-arabinose and exogenous AHL (data not shown). This therefore establishes that EsaR does not govern the esal-encoded signal synthesis; in fact, esal appears to be expressed constitutively.

\section{Purification of native EsaR protein}

DNA binding studies to establish the role of EsaR as a repressor in vitro require purified EsaR protein. Initial attempts to express EsaR as a $\mathrm{His}_{6}$-tagged fusion protein were hampered by protein solubility problems. We therefore opted to express EsaR in its native form in E. coli strain TM6, which harbours the recombinant plasmid pTDM6. This plasmid carries the esaR gene under the control of the L-arabinose inducible promoter, $\mathrm{P}_{\mathrm{BAD}}$ (Table 1 and Fig. 1A). EsaR protein was extracted from cultures grown in the presence of $0.02 \%$ L-arabinose and in the absence of the AHL ligand. This is an important point, because some LuxR-type proteins, most notably TraR, require $A H L$ ligand to remain soluble in cellular lysates (Zhu and Winans, 1999; Qin et al., 2001). Growth of strain TM6 at $28^{\circ} \mathrm{C}$ allowed the purification of native EsaR protein that, when purified by column chromatography, was soluble to $0.4 \mathrm{mM}$. Active fractions were identified by DNA mobility-shift assays against a synthetic DNA target. These fractions were pooled, aliquoted, and stored at $-80^{\circ} \mathrm{C}$ until needed for further biochemical analysis.

\section{Analysis of EsaR binding in DNA mobility-shift assays}

The in vivo data of Fig. 1 indicated that Apo-EsaR represses an esaR promoter gene fusion, presumably by 
1628 T. D. Minogue et al.

Table 2. Oligonucleotides and primers used in this study.

\begin{tabular}{lll}
\hline Fragment/primer & Sequence & Used for \\
\hline Fragments & & Mobility-shift assay (Fig. 2) \\
PesaR28 & 5'-TCTTGCCTGTACTATAGTGCAGGTTAAG & Mobility-shift assay (Fig. 2) \\
PesaR20 & 5'-AGAACGGACATGATATCACGTCCAATTC & \\
& 3'-CGGACATGATATCACGTCCA & Cloning esaR into pBAD22 \\
Primers & & SPR (Fig. 3) \\
F_esaRNcol & 5'-GAGCCATGGTTTCTTTTTTCC & \\
R_esaRHindIII & 5'-CCGCAAGCTTCAGTCACTAC & Cloning esal into pBBR1MCS-3 \\
F_esaR70 & 5'-Biotin-AGAAAACATTCAGGCTCCATGCTGCTTC & \\
R_esaR70 & 5'-TCTTGCCTGTACTATAGTGCAGGTTAAG-Biotin & \\
F_esalXbal & 5'-CAAGTTCTAGAAAACTGCGCCAGGTCAAC & \\
R_esallXmal & 5'-AACAGCCCGGGCATTCCATTTCC & \\
\hline
\end{tabular}

The underlined sequences indicate the esa $R$ box.

binding to the esaR box located in this region. We therefore assayed purified protein against synthetic target DNAs in DNA mobility-shift assays to define the in vitro DNA binding characteristics of EsaR. Apo-EsaR formed a specific complex with a $28 \mathrm{bp}$ DNA fragment bearing the native esaR box (Table 2). Moreover, the density of the shifted band, measured in digital pixels, was proportional to the amount of EsaR protein assayed (Fig. 2A, lanes 2-4). Addition of increasing levels of unlabelled probe DNA (20 mer esaR box) effectively inhibited complex formation (Fig. 2A, lanes 5-7) and produced a high intensity hybrid DNA species composed of labelled 28 mer and unlabelled 20 mer oligonucleotides that migrate between the $28 \mathrm{mer}$ double-stranded and single-stranded DNA forms. Higher order complexes of EsaR protein were only faintly detected at protein concentrations at or above $200 \mathrm{nM}$.

DNA mobility-shift assays using a wide range of protein concentrations against a constant amount of labelled probe DNA yielded a binding affinity of $3 \times 10^{-8} \mathrm{M}\left(\approx K_{\mathrm{D}}\right)$ for EsaR and the esaR box DNA palindrome (Fig. 2B). A calculated Hill coefficient of 0.99 indicates that EsaR binds the esaR box with little or no cooperativity. Interestingly, the addition of the $\mathrm{OHHL}$ signal ligand did not induce DNA-protein complex dissociation even when used at a concentration of $500 \mu \mathrm{M}$, and regardless of whether the protein was exposed to the signal ligand pre or post presentation of the DNA probe (Fig. 2A). This in vitro observation is puzzling considering that EsaR is highly responsive to $\mathrm{OHHL}$ in vivo.

\section{EsaR binds to the DNA as a dimer}

To further evaluate the oligomeric state of EsaR, we developed an assay based on the differential mobility of the native EsaR protein and a larger mass hybrid MBP-
EsaR protein. Specifically, we fused the malE gene to the $5^{\prime}$-end of the esa $R$ coding sequence separated by a Xa factor protease recognition linker sequence (Riggs, 2000). Standard DNA binding assays, containing affinitypurified MBP-EsaR, a radiolabelled $28 \mathrm{bp}$ esa $R$ promoter DNA fragment, and a constant amount of Xa factor, were incubated for different times before gel electrophoresis. Figure $2 \mathrm{C}$ shows that at zero time incubation the larger mass MBP-EsaR homodimer was present exclusively. Prolonged periods of incubation gradually yielded the MBP-EsaR::EsaR heterodimer of intermediate mobility, followed by complete transformation to the lower migrating EsaR::EsaR homodimer. The formation of only one intermediate complex suggests that EsaR binds the DNA target as a dimer under the conditions assayed. These observations are consistent with our previous size-exclusion chromatographic results, which show that Apo-EsaR fractionates with a relative molecular mass of dimeric EsaR (data not shown).

\section{Analysis of EsaR binding by surface plasmon resonance}

Surface plasmon resonance (SPR) is a refractometrybased technique that allows measurement of biomolecular interactions in real time as changes of mass concentrations on a sensor surface (Rich and Myszka, 2001). We used this method to gain additional insight into the in vitro molecular recognition dynamics of EsaR for its DNA target. A $70 \mathrm{bp}$ biotinylated PCR product of the native esa $R$ promoter was conjugated to a dextran streptavidincoated (SA) sensor chip at a surface density of 120 resonance units (RUs). Injection of EsaR protein analyte over a range of $\mathrm{nM}$ concentrations showed a steady increase in RUs with $344 \mathrm{nM}$ EsaR protein yielding a sensogram that reflects saturation binding (Fig. $3 A$ ). The $R U$ values 
A

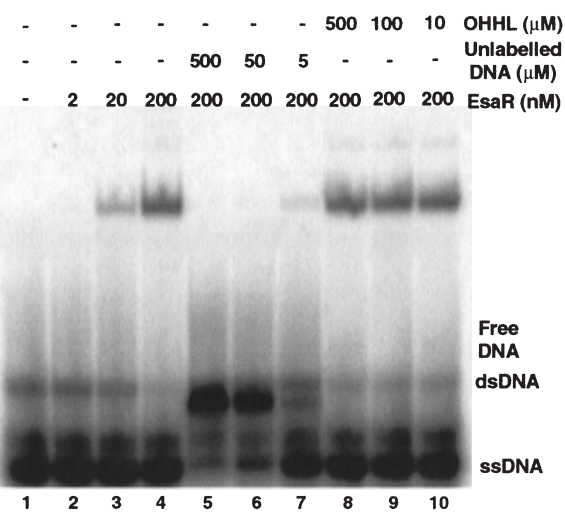

B

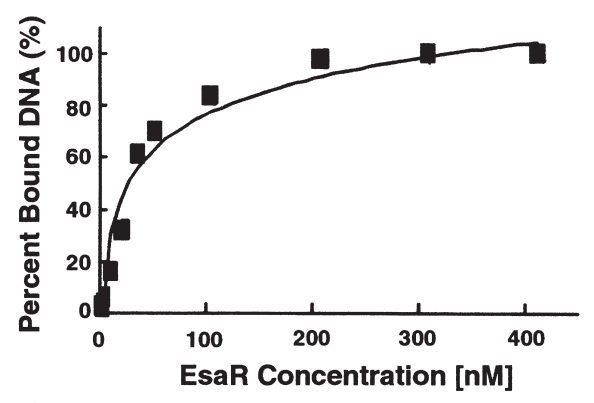

C
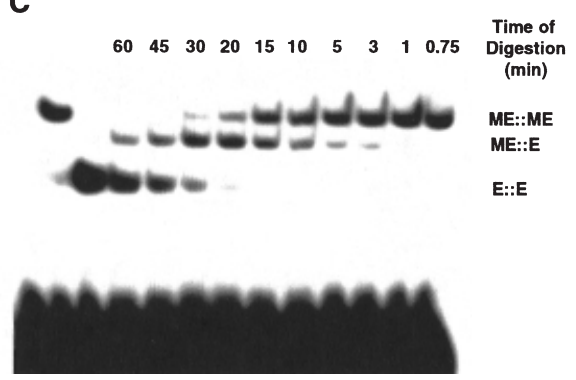

TCTTGCCTGTACTATAGTGCAGGTTAAG AGAACGGACATGATATCACGTCCATTCA

28mer

Fig. 2. Interaction of purified EsaR protein with target DNA. A. A synthetic, end-labelled 28 bp DNA fragment $(1.6 \mu \mathrm{M})$ containing the EsaR recognition sequence (lane 1) was incubated with 10 -fold increasing amounts ( 2 to $200 \mathrm{nM}$ ) of purified EsaR protein and resolved by native gel electrophoresis (lanes 2-4). Binding specificity of EsaR for the probe DNA was demonstrated with 10-fold increasing amounts of excess ( 5 to $500 \mu \mathrm{M}$ ) unlabelled competitor DNA bearing the 20 mer esaR box (lanes 5-7). Addition of $\mathrm{OHHL}$ at 10,100 and $500 \mu \mathrm{M}$ did not result in complex dissociation (lanes 8-10).

B. A binding constant $\left(K_{\mathrm{D}}\right)$ of $3 \times 10^{-8} \mathrm{M}$ was calculated based on the pixel intensity of free and complexed probe DNA recorded with a Bio-Rad phosphorimager and evaluated with IMAGER ONE software.

C. DNA mobility analysis of purified MBP-EsaR (M) hybrid protein treated with $\mathrm{Xa}$ factor protease at increasing incubation times resolves probe DNA complexed with the higher mass MBP-EsaR (M::M) homodimer, the MalE-EsaR::EsaR (M::E) heterodimer of intermediary mobility, and eventual complete conversion to the lower mass EsaR::EsaR (E::E) homodimer. Lane 1 resolves the $M: M$ homodimer at 0 time incubation; lane 2 shows the $E: E$ homodimer after $2 \mathrm{~h}$ of $\mathrm{Xa}$ factor treatment. of the sensograms displayed were corrected for nonspecific interactions between EsaR protein and a similar length non-target DNA measured in a parallel reference cell. The data were analysed with the BIAEVALUATION 3.0 software, assuming a simple 1:1 Langmuir binding model to determine a $K_{\mathrm{D}}$ value of $9 \times 10^{-9} \mathrm{M}\left(\chi^{2}=6.01\right)$. This binding constant is in good agreement with the $3 \times$ $10^{-8} \mathrm{M}$ value derived from DNA mobility-shift assays (Fig. 2B).

Surface plasmon resonance analysis using the same sensor chip and a constant EsaR concentration of $344 \mathrm{nM}$, but varying amounts of $\mathrm{AHL}$ in the buffer system during the association phase of the experiment yielded proportionally lower RU values (Fig. 3B). The sensograms were similar to those obtained when measuring lower EsaR protein concentrations (Fig. 3A). These results suggest that signal ligand may prevent AHL-bound EsaR from interacting with the immobilized DNA target thereby reducing the effective concentration of binding competent EsaR protein.
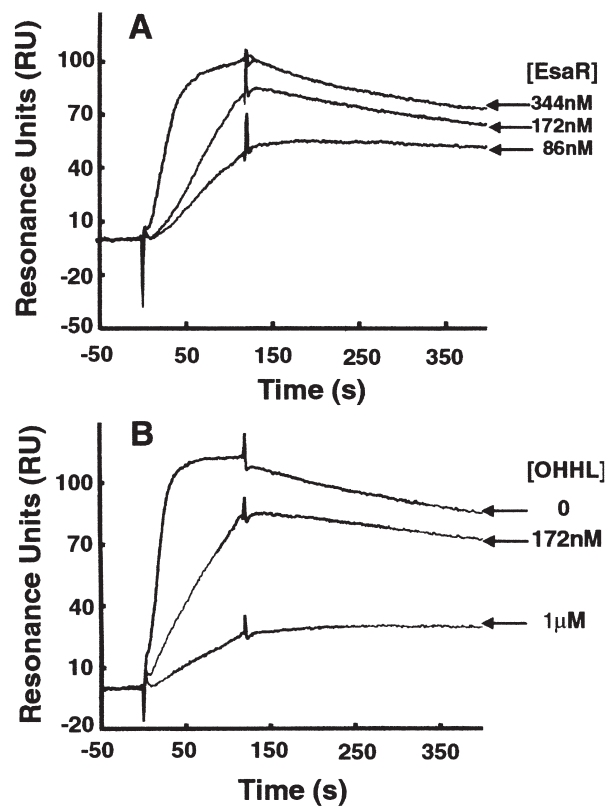

Fig. 3. Interaction of purified EsaR protein with a PCR-generated DNA fragment containing the esaR box evaluated by SPR refractometry.

A.The target DNA was immobilized on a SA strepdavidin-coated gold sensory chip at $120 \mathrm{RU}$ (1:1 Rmax of 120). EsaR protein analyte was injected over a range of concentrations $(22 \mathrm{nM}$ to 1.4 $\mu \mathrm{M}$, displayed are 86,172 and $344 \mathrm{nM}$ ) at a flow rate of $25 \mu \mathrm{min}^{-1}$ with an association time of $180 \mathrm{~s}$, and a dissociation time of $600 \mathrm{~s}$ (shown only $350 \mathrm{~s}$ ).

B. SPR assay with $344 \mathrm{nM}$ EsaR protein and $0,172 \mathrm{nM}$ and $1 \mu \mathrm{M}$ concentrations of $\mathrm{OHHL}$ added to the buffering system during the association phase only. The $\mathrm{RU}$ values shown in both sensograms are difference RU values of the sample cell and parallel reference cell measuring the non-specific protein-DNA interactions. 

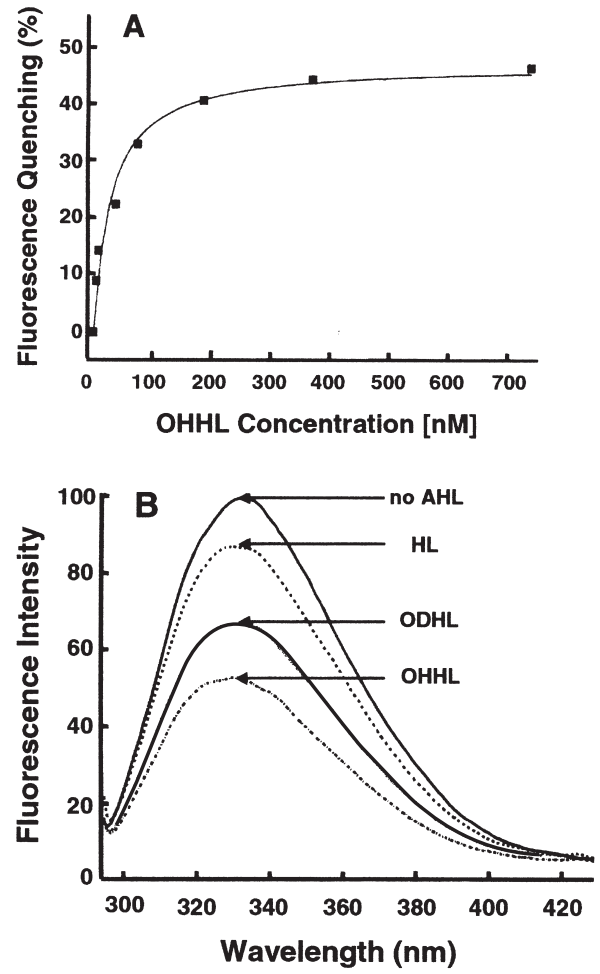

Fig. 4. Biophysical analysis of EsaR- $N$-acyl-homoserinelactone $(\mathrm{AHL})$ interactions. The EsaR fluorescence was determined at a concentration of $370 \mathrm{nM}$.

A. EsaR titration with increasing amounts of $\mathrm{OHHL}$ at $0,3.7,7.4$ $37,74,185,470,740 \mathrm{nM}$ and $3.7 \mu \mathrm{M}$.

B. Interaction of EsaR with $3.7 \mu \mathrm{M} \mathrm{OHHL}, N$-(3-oxo-dodecanoyl)-Lhomoserine $(\mathrm{ODHL})$, and L-homoserine lactone $(\mathrm{HL})$.

\section{Analysis of the EsaR/AHL interaction by} fluorescence spectroscopy

EsaR contains three tryptophan residues; two located in the $N$-terminal region (W54 and W82) and one (W191) in the C-terminal helix-turn-helix domain. LuxR homologue proteins utilise regions in the $\mathrm{N}$-terminus to dimerize and to bind signal ligand (Choi and Greenberg, 1992; Hanzelka and Greenberg, 1995; Qin et al., 2001; Zhu and Winans, 2001). Such intermolecular interactions generally invoke structural changes, which, in turn, alter the intrinsic fluorescence intensity of the protein. We took advantage of the intrinsic fluorescence of EsaR to assess the effect of ligand binding on the structural integrity of the protein (Fig. 4A). Measurements taken at wavelengths between $300 \mathrm{~nm}$ and $400 \mathrm{~nm}$ produced a fluorescence maximum around $340 \mathrm{~nm}$. This fluorescence decreased in intensity with increasing concentrations of the $\mathrm{OHHL}$ ligand. Maximal quenching of approximately $50 \%$ required $370 \mathrm{nM}$ ligand, and higher concentrations did not further quench fluorescence. These assays employed $370 \mathrm{nM}$ EsaR, therefore suggesting a 1:1 molar ratio of protein-ligand interaction. These results agree with similar fluorescence studies reported previously for CarR (Welch et al., 2000).

The specificity of EsaR for its signal ligand may vary depending on the length and substitution of the acyl side chain. Comparative fluorescence data obtained from separate experiments containing equal amounts of either L-homoserine lactone (HL), N-(3-oxododecanoyl)-L-homoserine Lactone (ODHL) and OHHL, gave different intrinsic fluorescence spectra (Fig. 4B). The signal ligands were added in 10-fold molar excess and the recorded reductions in EsaR fluorescence were 50\%, $35 \%$ and $15 \%$ respectively. These data suggest that EsaR binds the physiologically relevant $\mathrm{OHHL}$ species most efficiently, shows reduced affinity for ODHL, and has minimal affinity for the $\mathrm{HL}$ moiety alone.

EsaR is more heat-stable in the presence of the signal ligand

We wished to evaluate whether the addition of the preferred ligand, OHHL, affects the stability of the EsaR protein and/or prevents the purified EsaR protein from precipitation at extremely high concentrations. We therefore monitored the effect of OHHL on the thermal stability of purified EsaR by circular dichroism (CD) spectroscopy. As shown in Fig. 5A, the thermal stability of Apo-EsaR was relatively low with denaturation beginning at $48^{\circ} \mathrm{C}$ and completed at $58^{\circ} \mathrm{C}$. The addition of 10 -fold excess OHHL increased the thermal stability of EsaR by about $10^{\circ} \mathrm{C}$, with no denaturation seen below $53^{\circ} \mathrm{C}$ and complete denaturation requiring $68^{\circ} \mathrm{C}$ (Fig. 5B).

\section{Discussion}

This study establishes several critical facts related to the role of EsaR as a repressor of QS in P. stewartii. First, it demonstrates that EsaR regulates its own expression by repression and $\mathrm{AHL}$-mediated derepression; second, that purified EsaR dimerizes and binds DNA without AHL ligand; third, that $\mathrm{AHL}$ interacts specifically with EsaR protein, and induces structural changes that may neutralise its DNA binding affinity; and fourth, that EsaR has no role in the control of the linked signal synthase gene, esal. These data correlate well with our earlier prediction that EsaR functions as a repressor of CPS synthesis in P. stewartii (von Bodman and Farrand, 1995; von Bodman et al., 1998).

A mechanism for QS by repression is unexpected because the majority of LuxR-type regulators are signalresponsive transcription activators (Fuqua et al., 1996, 2001; Whitehead et al., 2001). The LuxR class of proteins exhibits an overall sequence identity of $18-25 \%$, with three critical regions of higher conservation (Whitehead et al., 2001). These include an $\mathrm{N}$-terminal region for 

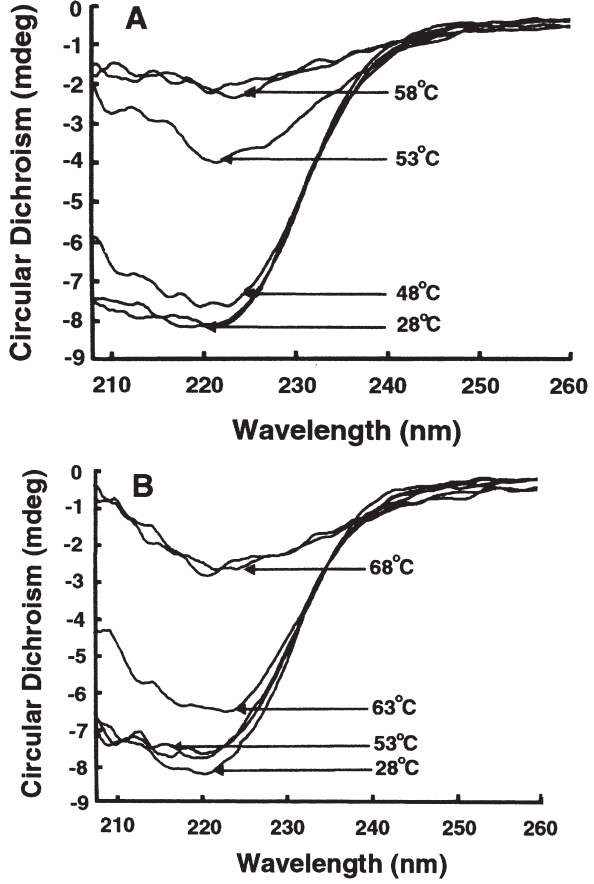

Fig. 5. Thermal stability of EsaR with and without AHL. Circular dichroism (CD) spectra of $370 \mathrm{nM}$ EsaR were determined at increasing temperatures in the absence and presence of OHHL. The bottom curve in both diagrams represent the spectrum at $28^{\circ} \mathrm{C}$, the top curves represent the spectrum at the highest temperature.

A. CD spectra without $\mathrm{OHHL}$ measured at temperatures ranging from $28^{\circ} \mathrm{C}$ to $63^{\circ} \mathrm{C}$.

B. CD spectra with $\mathrm{OHHL}$ measured at temperatures ranging from $28^{\circ} \mathrm{C}$ to $73^{\circ} \mathrm{C}$

$\mathrm{AHL}$ signal binding, a more centrally located domain for protein oligomerization, and a helix-turn-helix C-terminal domain for DNA binding (Stevens and Greenberg, 1999; Fuqua et al., 2001; Whitehead et al., 2001). However, the QS regulatory proteins found in Erwinia-type bacterial species, including EsaR of $P$. stewartii (formerly $E$. stewartii) (von Bodman and Farrand, 1995), CarR (Welch et al., 2000) and ExpR of Erwinia carotovora ssp. carotovora (Ecc) (Andersson et al., 2000), have a higher degree of relatedness among them. This subfamily of QS regulators is also distinctive in its ability to dimerize and bind DNA in the absence of signal ligand. Based on these characteristics, it was proposed that the LuxR-type proteins fall into two basic groups (Andersson et al., 2000; Qin et al., 2001; Whitehead et al., 2001).

We propose here that the CarR, ExpR and EsaR, subfamily of QS regulators can be divided further based on their discrete functional differences. Specifically, CarR, the QS regulator of carbapenem synthesis in E. carotovora (Ecc) dimerizes and binds DNA in the absence of $\mathrm{AHL}$, but forms higher order complexes in the presence of inducing amounts of $\mathrm{AHL}$ to promote activation of the car target gene system (Welch et al., 2000). In fact, muta- tional disruption of CarR results in a null-carbapenem phenotype (McGowan et al., 1995). CarR also controls its own expression by AHL-dependent activation (Whitehead et al., 2001). The ExpR regulatory proteins described for two different E. carotovora strains (Andersson et al., 2000) (Whitehead et al., 2001) and Erwinia chrysanthemi (Nasser et al., 1998) also bind target promoters in an AHL-free state, and were thought to control exoenzyme synthesis negatively. However, mutational inactivation of the $\exp R$ gene has no, or only a minor, effect on exoenzyme expression. The implication is that in these strains $Q S$ regulation is redundant and that the repressive role of ExpR may be one of $\mathrm{AHL}$ sequestration rather than direct regulation (Andersson et al., 2000). The ExpR protein of E. chrysanthemi was also shown to bind to the $\exp R$ promoter at a well conserved lux box palindrome (Reverchon et al., 1998; Andersson et al., 2000). However, mutational inactivation of ExpR had no effect on expR expression (Reverchon et al., 1998).

EsaR, in contrast to ExpR and CarR, has a well defined activity as a repressor of its own expression, and the hypermucoid phenotype of esaR null mutants suggests that it represses CPS synthesis as well. Specifically, EsaR negatively regulates an esaR::lacZ reporter gene expressed in vivo in $E$. coli in a dose-dependent manner (Fig. 1B), and EsaR responds rapidly to exogenously provided $\mathrm{AHL}$ for derepression (Fig. $1 \mathrm{C}$ ). The in vitro binding properties of EsaR support the genetic data showing that Apo-EsaR exists primarily as a homodimer complex and exhibits specificity for the esaR box DNA target with an affinity characteristic of these proteins (Fig. 2A and C). In addition, higher order oligomeric complexes of EsaR, characteristic of CarR and ExpR, are detected only when assaying EsaR protein at or above $200 \mathrm{nM}$ concentrations, with or without OHHL present (Fig. 2B). A significant inconsistency between the in vivo and in vitro data is the observation that addition of $\mathrm{OHHL}$ does not promote EsaR-DNA complex dissociation in the DNA mobilityshift assays (Fig. 2A). This is surprising for three reasons. First, the fluorescence-quenching experiments (Fig. 4) show that $\mathrm{OHHL}$ interacts specifically and stoichiometrically with purified EsaR protein. Second, the SPR data (Fig. 3B) show that when EsaR is exposed to increasing levels of $\mathrm{OHHL}$, the concentration of binding competent EsaR decreases proportionally. Third, ExpR of $E$. chrysanthemi releases DNA in response to AHL, although the ligand concentrations used in the ExpR DNA mobilityshift assays (Reverchon et al., 1998) were substantially higher than the amounts used in the current study. The SPR data indicate that $A H L$ reduces the binding affinity of Apo-EsaR. However, additional SPR experiments are needed to establish whether AHL promotes DNA-protein complex dissociation, or whether DNA bound EsaR protein has a structural conformation that is unfit to per- 
ceive the AHL signal. AHL-mediated derepression of the esaR reporter gene fusion in vivo is rapid regardless of the time lag between arabinose induction to express EsaR and the addition of OHHL (Fig. 1C). These data suggest that holoenzyme formation does not require nascent protein synthesis as is predicted for TraR protein of Agrobacterium tumefaciens (Zhu and Winans, 1999). In A. tumefaciens, AHL is thought to serve as a scaffold for proper TraR folding and protection from cellular proteolysis. Presumably, EsaR folds properly in the absence of $\mathrm{AHL}$ to assume a stable, DNA binding-proficient conformation. It is conceivable, that preformed Apo-EsaR undergoes an $\mathrm{AHL}$-induced structural transformation that perturbs the binding domain, or causes the protein dimer to dissociate into AHL-bound monomers. In either case, AHL may render EsaR protein susceptible to proteolysis. Proteolytic inactivation of EsaR could account for the rapid derepression observed in vivo, while also explaining the inability of AHL to induce complex dissociation in the in vitro DNA mobility-shift assays. Experiments are in progress to test whether proteolysis is a factor in the mechanism of AHL-dependent derepression of EsaR.

A model by Qin and colleagues (Qin et al., 2001) proposes that Apo-TraR of $A$. tumefaciens partitions to the cytoplasmic membrane to isolate monomeric TraR from the pool of intracellular AHL under non-inducing conditions. It is proposed that TraR dissociates from the membrane and dimerizes when the membrane-permeable AHL concentration reaches inducing levels. In contrast, EsaR does not appear to be membrane-associated; in fact, EsaR is soluble in its native form without AHL ligand, unlike TraR. If, as predicted, membrane association is to prevent premature TraR dimerization, then EsaR protein may not share this requirement because it is naturally dimeric and seeks DNA targets under AHL-limiting conditions.

EsaR is highly responsive to AHL-induced derepression in the control of its own gene expression. More significantly, it responds gradually and proportionally to the amount of $\mathrm{AHL}$ provided, not suddenly at a given inducing concentration. If this reflects the normal dynamics of EsaR and AHL co-inducer interaction, then it is unclear how EsaR governs the expression of CPS synthesis in a strictly cell density-dependent manner when AHL production is constitutive. We suggest that $\mathrm{AHL}$-induced derepression of the esaR gene may be important in this respect. Specifically, we propose that increased cellular levels of EsaR sequester the constitutively generated cellular pools of $\mathrm{AHL}$ to prevent premature derepression of CPS synthesis at lower cell densities. Accordingly, a cell population would become 'quorate' when the cellular levels of $\mathrm{AHL}$ exceed the maximum levels of EsaR expressed. This rationale would explain also the apparent paradox of AHL-dependent derepression of the esaR gene to generate more of the QS repressor when approaching AHL-inducing conditions. EsaR-mediated autorepression may also serve as an intrinsic mechanism of QS modulation.

$\mathrm{N}$-Acyl-homoserinelactone (AHL) signal synthesis in $P$. stewartii is independent of EsaR and appears to be constitutive. This is in contrast to the paradigm of $Q S$ regulation that requires LuxR-AHL activation of the cognate lux/ signal synthase gene. It is difficult to predict when and why esal regulation became EsaR-independent; but it may have been in response to EsaR assuming a role as a repressor, because repression of the esal gene may be counterproductive in the overall scheme of QS. Conversely, EsaR may have assumed a repressor role in response to deregulated synthesis of $\mathrm{AHL}$ to preserve the QS control of CPS synthesis and virulence. We know from previous studies that the deregulated synthesis of CPS is disadvantageous for $P$. stewartii to successfully colonize the plant host (von Bodman and Farrand, 1995).

Finally, we wish to emphasize that we cannot rule out the possibility that EsaR may function under certain conditions also as a gene activator, nor can we predict at this stage whether the expression of the cps gene system is under the direct control of EsaR. We have to consider the formal possibility that the main role of EsaR is to sequester cellular $\mathrm{AHL}$ and that a second $\mathrm{QS}$ regulatory system may actually govern CPS synthesis. However, such a mechanism is difficult to reconcile with the fact that the esal-esaR double mutant $P$. stewartii strain ES $\Delta I R$ exhibits a hypermucoid phenotype in absence of cellular EsaR or AHL. Experiments to define the role of EsaR in the control of CPS and to search for additional QS systems in $P$. stewartii are in progress.

\section{Experimental procedures}

\section{Bacterial strains, plasmids, oligonucleotides and DNA techniques}

The Escherichia coli strains DH5 $\alpha$ (Life Technologies) and $\mathrm{Top}_{10}$ (Invitrogen) were used as cloning hosts and were grown at $37^{\circ} \mathrm{C}$ on nutrient agar plates, Luria-Bertani (LB) broth, M9 minimal, or RM medium $(1 \times \mathrm{M} 9$ salts, $1 \mathrm{mM} \mathrm{MgCl}$, $2 \%$ casamino acids, $0.4 \%$ glucose) in presence of $100 \mathrm{\mu g} \mathrm{ml}^{-1}$ of ampicillin, $10 \mu \mathrm{g} \mathrm{ml}^{-1}$ of tetracycline, and $10 \mu \mathrm{g} \mathrm{ml}^{-1}$ of kanamycin, where applicable. All relevant plasmids and strains are listed in Table 1. The stewartii strains were grown at $28^{\circ} \mathrm{C}$ in LB in presence of $30 \mu \mathrm{g} \mathrm{ml}^{-1}$ of nalidixic acid. DNA techniques were performed by standard methods as described (von Bodman and Farrand, 1995; von Bodman et al., 1998). DNA fragments were amplified using Ex Taq Polymerase (Takera/Panvera) and synthetic oligonucleotides (Table 2) ordered to specification from Sigma Genosys.

\section{Plasmid constructions}

We amplified the esaR gene using PCR primers, F_esaRN- 
col and R_esaRHindIII (Table 2) to create a $5^{\prime}$-Ncol cloning site to overlap and include the ATG translation initiation codon, and a 3' Hindlll site downstream of the stop codon. This fragment was inserted into the similarly digested expression vector, pBAD22 (Guzman et al., 1995) resulting in plasmid pTDM6 (Fig. 1A). The esaR gene was re-cloned as a Pstl-Sall fragment from plasmid pSVB5-18 (von Bodman and Farrand, 1995) into the broad-host-range vector, pBBR1MCS-3 (Kovach et al., 1995) to generate plasmid pSVB60 (Table 1). This plasmid was used to create a translational reporter gene fusion by inserting the lacZY$\mathrm{Km}^{R}$ cassette from plasmid pLKC481 (Tiedeman and Smith, 1988) cloned as an Xmal fragment into the internal Mrol site to generate pTDM7 (Fig. 1A and Table 1). Polymerase chain reaction (PCR) amplification of the esal promoter and partial coding sequence used primers $F_{-}$esalXbal and $\mathrm{R} \_$esalXmal that provided 5'-Xbal and $3^{\prime}-X m a l$ restriction sites (Table 2) for cloning into plasmid pBBR1MCS-3 to create pTDM18 (Table 1). Plasmid pTDM18 was used to create an in-frame reporter gene fusion by linking the lacZYKm ${ }^{R}$ cassette released as a Xmal fragment from plasmid pLKC480 (Tiedeman and Smith, 1988) to the esal coding sequence at the Xmal site to create pTDM19 (Table 1).

\section{$\beta$-Galactosidase activity assay}

Production of $\beta$-galactosidase was quantified as described (von Bodman and Farrand 1995). Cells were grown in RM minimal medium, diluted to an optical density $(O D)_{600}$ of 0.05 and allowed to grow to an $\mathrm{OD}_{600}$ of 0.1 before inducing with L-arabinose. $\mathrm{N}$-(3-oxo-hexanoyl)-L-homoserine lactone $(\mathrm{OHHL})$ was supplied at the indicated concentrations either at the point of L-arabinose induction, or at defined times post $L$-arabinose induction. $\beta$-Galactosidase levels were expressed as $\beta$-galactosidase units (Sambrook et al., 1989) or $\beta$-galactosidase activity (Miller, 1972). Each experiment was performed in triplicate and was repeated at least two times.

\section{Expression and purification of EsaR protein}

Native EsaR protein was purified from $E$. coli strain $\mathrm{TOP}_{10}$ (pTM6). This strain was grown at $28^{\circ} \mathrm{C}$ in 1 I of LB containing $100 \mathrm{~g} \mathrm{ml}^{-1}$ of ampicillin. The cells were harvested when the culture reached an optical density $\mathrm{OD}_{600}$ of 0.6 , resuspended in $10 \%$ glycerol, and stored as stock inocula at $-80^{\circ} \mathrm{C}$. Cells from $18 \mathrm{I}$ volume fermentations, induced with $0.02 \%$ L-arabinose at an $\mathrm{OD}_{600}$ of 0.6 were harvested $4 \mathrm{~h}$ post induction. The cells were resuspended in $180 \mathrm{ml}$ of buffer (50 mM Tris, pH 7.5, 10\% glycerol) and broken by three passages through a French press (20000 psi). Cell debris was removed by centrifugation $(30000 \mathrm{~g}$ for $30 \mathrm{~min}$ ) and the soluble fraction was passed through a $0.2 \mu \mathrm{m}$ cellulose filter (Millipore) before fractionation by heparin affinity perfusion chromatography (BioCAD, Poros 20HE). The column was equilibrated with $450 \mathrm{ml}$ of TBP buffer $(20 \mathrm{mM}$ Tris bispropane buffer, $\mathrm{pH} 7.5)$. The soluble lysate was applied to the column in four $5 \mathrm{ml}$-volume injections and the column was washed with $20 \mathrm{ml}$ of TBP buffer after each injection. Bound protein was eluted with a two-step gradient of TBP buffer con- taining $400 \mathrm{mM}$ and $800 \mathrm{mM} \mathrm{NaCl}$ respectively. Fractions containing EsaR were identified by standard 15\% SDS-polyacrylamide gel electrophoresis (SDS-PAGE) using protein molecular weight markers (prestained, broad range, New England Biolabs) for size reference, and differential expression of EsaR protein in un-induced and arabinose-induced lysates. Fractions containing EsaR were pooled and concentrated 16-fold with a Centriprep YM-10 filter (Millipore). The filtrate was applied to a size exclusion column (S-100 Sephracyl, 100KD exclusion) and eluted with a 1 bed-volume of TNG buffer (20 mM Tris, pH7.5, $500 \mathrm{mM} \mathrm{NaCl}, 10 \%$ glycerol). Fractions containing EsaR were identified by SDS-PAGE. EsaR was stored in TNG at $-80^{\circ} \mathrm{C}$.

\section{Gel retardation assays}

Synthetic DNA fragments used in these assays are listed in Table 2. Double-stranded DNA was obtained by mixing complementary oligodeoxyribonucleotides heated to $95^{\circ} \mathrm{C}$ and slowly cooled to room temperature. These DNAs were labelled at their $3^{\prime}$-ends with $\left[\alpha-{ }^{32} \mathrm{P}\right]-\mathrm{dATP}$, specific activity $3000 \mathrm{Cimmol}^{-1}$ (Perkin Elmer) in presence of Klenow DNA polymerase (Amersham). DNA binding reactions used varying concentrations of purified EsaR incubated at $28^{\circ} \mathrm{C}$ for $30 \mathrm{~min}$ with $1.6 \mu \mathrm{M}$ concentration of ${ }^{32} \mathrm{P}$-labelled DNA fragments in $20 \mu \mathrm{l}$ reactions using a buffer consisting of $20 \mathrm{mM}$ Hepes, pH 7.6, $1 \mathrm{mM}$ EDTA, $10 \mathrm{mM}\left(\mathrm{NH}_{4}\right)_{2} \mathrm{SO}_{4}, 1 \mathrm{mM}$ DTT, $0.2 \%$ Tween-20, $30 \mathrm{mM} \mathrm{KCl}, 50 \mathrm{mg} \mathrm{ml}^{-1}$ of uncut $\lambda$-DNA and $150 \mu \mathrm{g} \mathrm{ml}^{-1}$ of BSA. After adding $5 \mu \mathrm{l}$ of loading buffer, each reaction mixture was fractionated by electrophoresis at $4^{\circ} \mathrm{C}$ on a native $6 \%$ polyacrylamide gel in $1 \times$ TBE buffer (TrisBorate-EDTA, electrophoresis grade, Fisher Biotech). Gels were dried using a vacuum gel drier. An imaging screen-K (Bio-Rad) was exposed overnight and phosphorescence signal was detected with the Molecular Imager FX system (Bio-Rad). The bands were analysed with QUANTITY ONE quantification software (Bio-Rad).

\section{Surface plasmon resonance technique}

A BIAcore $X$ instrument (BIAcore) was used to perform SPR measurements (Rich and Myszka, 2001). Activation of the SA streptavidin-coated sensor chip was performed following the manufacturer's recommended procedure. Non-specific and specific biotinylated DNA were coupled to a streptavidin matrix of two separate chips to yield approximately 120 resonance units (RU). The resulting sensor chips were analysed in parallel flowcells. All experiments were carried out at a flow rate of $25 \mu \mathrm{min}^{-1}$. EsaR analyte was presented in a running buffer $(50 \mathrm{mM}$ Tris, $\mathrm{pH} 7.5,100 \mathrm{mM} \mathrm{NaCl}, 10 \mathrm{mM}$ DTT, $0.1 \mathrm{mM}$ EDTA). Bovine serum albumin (BSA) $\left(200 \mathrm{ng}^{\mu \mathrm{l}^{-1}}\right)$ and $\lambda$-DNA ( $8 \mathrm{ng} \mu \mathrm{l}^{-1}$ ) were added to each protein sample before injection. Protein mixtures containing various concentrations (ranging from $22 \mathrm{nM}$ to $1.4 \mu \mathrm{M}$ ) of purified EsaR protein were injected allowing an association time of $180 \mathrm{~s}$ and a dissociation time of $350 \mathrm{~s}$. The reference flow cell featuring a random DNA target of the same size as the probe DNA was used to subtract unspecific DNA-protein interactions. Regeneration of the chip surface was achieved by removing all bound proteins with a pulse of $5 \mathrm{ml}$ of $0.05 \%$ 
1634 T. D. Minogue et al.

SDS in running buffer. Data analysis was performed using the BIAEVALUATION 3.0 program to determine the binding properties of the protein assuming 1:1 Langmuir kinetics.

\section{MBP-EsaR hybrid protein}

The EsaR protein was expressed from plasmid pMBP-EsaR that features the esaR coding sequence cloned into the pMAL-c2x plasmid (New England Biolabs) to generate a Cterminal fusion to the maltose-binding protein for expression in E. coli host strain TB1. The hybrid protein was purified by amylose resin (New England Biolabs) affinity chromatography. Bound proteins were eluted using four volumes of buffer (20 mM Tris, $1 \mathrm{mM}$ EDTA, $200 \mathrm{mM} \mathrm{NaCl}$ ) with a linear gradient of maltose from $0 \mathrm{mM}$ to $0.6 \mathrm{mM}$. Proteolytic cleavage of the hybrid protein was achieved with Xa factor (New England Biolabs), using supplier-recommended conditions and varying times of incubation. DNA mobility-shift assays were performed as described above.

\section{Fluorescence spectroscopy}

Fluorescence measurements were performed with a Shimadzu RF-5001 PC spectrofluorimeter equipped with a Hellma Cuv-O-Stir magnetic cuvette stirrer and a Lauda RM6 thermostat. All experiments were carried out in $50 \mathrm{mM}$ Tris $\mathrm{pH} 7.5,100 \mathrm{mM} \mathrm{NaCl}, 0.1 \mathrm{mM}$ EDTA. Purified EsaR protein was used for all experiments. Before measuring, the cuvettes containing $1.5 \mathrm{ml}$ of the samples were equilibrated to $28^{\circ} \mathrm{C}$ and carefully stirred to ensure homogeneity. Spectra between $290 \mathrm{~nm}$ and $480 \mathrm{~nm}$ were recorded with an excitation wavelength of $284 \mathrm{~nm}$ and a scan speed of $0.8 \mathrm{~nm}$ per second. To avoid errors caused by sample dilution, the autoinducer titrations were performed by adding $1 \mu$ l of suitable stock solutions.

\section{Circular dichroism measurements}

Measurements were obtained with a Jasco J-600 spectropolarimeter equipped with a Lauda RC6 thermostat. All experiments were carried out in $20 \mathrm{mM}$ Hepes pH7.0, $500 \mathrm{mM}$ $\mathrm{NaCl}, 5 \%$ glycerol. Spectra from $200 \mathrm{~nm}$ to $260 \mathrm{~nm}$ were recorded using a cuvette of $2 \mathrm{~mm}$ path length at a scanning speed of $20 \mathrm{~nm}$ per minute. For each temperature, the cuvette was allowed to equilibrate for $10 \mathrm{~min}$ before recording the spectrum.

\section{Acknowledgements}

We thank Professor Wolfram Sänger for inviting and supporting T.D.M. to visit his laboratory and to conduct part of this work at the Institut für Kristallographie, Freie Universität Berlin. We are grateful to Werner Schröder for supplying us with oligonucleotides, and J. Schneider-Mergener and C. Landgraf for use of the BIAcore instrument. We also thank John Clark, Clay Fuqua and Maria Koutsoudis for helpful discussions and critical evaluation of this manuscript. This work was supported in part by the USDA Agricultural Experiment Station grant CONSOO712 to S.B.vonB.

\section{References}

Andersson, R.A., Eriksson, A.R., Heikinheimo, R., Mae, A., Pirhonen, M., Koiv, V., et al. (2000) Quorum sensing in the plant pathogen Erwinia carotovora subsp. carotovora: the role of $\operatorname{expR}(E c c)$ Mol Plant Microbe Interact 13: 384-393.

Bassler, B.L., Wright, M., and Silverman, M.R. (1994) Multiple signalling systems controlling expression of luminescence in Vibrio harveyi: sequence and functions of genes encoding a second sensory pathway. Mol Microbiol 13: 273-286.

Bernhard, F., Coplin, D.L., and Geider, K. (1993) A gene cluster for amylovoran synthesis in Erwinia amylovora: characterization and relationship to cps genes in Erwinia stewartii. Mol Gen Genet 239: 158-168.

von Bodman, S.B., and Farrand, S.K. (1995) Capsular polysaccharide biosynthesis and pathogenicity in Erwinia stewartii require induction by an $\mathrm{N}$-acyl-homoserine lactone autoinducer. J Bacteriol 177: 5000-5008.

von Bodman, S.B., Majerczak, D.R., and Coplin, D.L. (1998) A negative regulator mediates quorum-sensing control of exopolysaccharide production in Pantoea stewartii subsp. stewartii. Proc Natl Acad Sci USA 95: 7687-7692.

Choi, S.H., and Greenberg, E.P. (1992) Genetic evidence for multimerization of LuxR, the transcriptional activator of Vibrio fischeri luminescence. J Bacteriol 174: 4064-4069.

Coplin, D.L., Frederick, R.D., Majerczak, D.R., and Tuttle, L.D. (1992) Characterization of a gene cluster that specifies pathogenicity in Erwinia stewartii. Mol Plant-Microbe Interact 5: 81-88.

Dolph, P.J., Majerczak, D.R., and Coplin, D.L. (1988) Characterization of a gene cluster for exopolysaccharide biosynthesis and virulence in Erwinia stewartii. J Bacteriol 170: 865-871.

Dunny, G.M., and Leonard, B.A. (1997) Cell-cell communication in Gram-positive bacteria. Annu Rev Microbiol 51: 527-564.

Fuqua, C., and Winans, S.C. (1996) Conserved cis-acting promoter elements are required for density-dependent transcription of Agrobacterium tumefaciens conjugal transfer genes. J Bacteriol 178: 435-440.

Fuqua, W.C., Winans, S.C., and Greenberg, E.P. (1994) Quorum sensing in bacteria: the LuxR-Luxl family of cell density-responsive transcriptional regulators. I Bacteriol 176: 269-275.

Fuqua, C., Winans, S.C., and Greenberg, E.P. (1996) Census and consensus in bacterial ecosystems: the LuxR-Luxl family of quorum-sensing transcriptional regulators. Annu Rev Microbiol 50: 727-751.

Fuqua, C., Parsek, M.R., and Greenberg, E.P. (2001) Regulation of gene expression by cell-to-cell communication: acyl-homoserine lactone quorum sensing. Annu Rev Genet 35: 439-468.

Gottesman, S., and Stout, V. (1991) Regulation of capsular polysaccharide synthesis in Escherichia coli K12. Mol Microbiol 5: 1599-1606.

Guzman, L.M., Belin, D., Carson, M.J., and Beckwith, J. (1995) Tight regulation, modulation, and high-level expression by vectors containing the arabinose PBAD promoter. $J$ Bacteriol 177: 4121-4130.

Hanzelka, B.L., and Greenberg, E.P. (1995) Evidence that 
the N-terminal region of the Vibrio fischeri LuxR protein constitutes an autoinducer-binding domain. J Bacteriol 177: 815-817.

Hwang, I., Li, P.L., Zhang, L., Piper, K.R., Cook, D.M., Tate, M.E., and Farrand, S.K. (1994) Tral, a Luxl homologue, is responsible for production of conjugation factor, the $\mathrm{Ti}$ plasmid N-acylhomoserine lactone autoinducer. Proc Natl Acad Sci USA 91: 4639-4643.

Kelm, O., Kiecker, C., Geider, K., and Bernhard, F. (1997) Interaction of the regulator proteins RcsA and RcsB with the promoter of the operon for amylovoran biosynthesis in Erwinia amylovora. Mol Gen Genet 256: 72-83.

Kleerebezem, M., and Quadri, L.E. (2001) Peptide pheromone-dependent regulation of antimicrobial peptide production in Gram-positive bacteria: a case of multicellular behavior. Peptides 22: 1579-1596.

Kovach, M.E., Elzer, P.H., Hill, D.S., Robertson, G.T., Farris, M.A., Roop,R.M.I.I., and Peterson, K.M. (1995) Four new derivatives of the broad hostrange cloning vector pBBR1MCS carrying different antibiotic resistance cassettes. Gene 166: 175-176.

McGowan, S., Sebaihia, M., and Jones, S., Yu B., Bainton, N., Chan, P.F., et al. (1995) Carbapenem antibiotic production in Erwinia carotovora is regulated by CarR, a homologue of the LuxR transcriptional activator. Microbiology 141: $541-508$.

Miller, J.H. (1972) Experiments in Bacterial Genetics. Cold Spring Harbor, New York: Cold Spring Harbor Laboratory Press.

Miller, M.B., and Bassler, B.L. (2001) Quorum sensing in bacteria. Annu Rev Microbiol 55: 165-199.

Nasser, W., Bouillant, M.L., Salmond, G., and Reverchon, S. (1998) Characterization of the Erwinia chrysanthemi expl-expR locus directing the synthesis of two $\mathrm{N}$-acylhomoserine lactone signal molecules. Mol Microbiol 29: 1391-1405.

Pesci, E.C., Pearson, J.P., Seed, P.C., and Iglewski, B.H. (1997) Regulation of las and rhl quorum sensing in Pseudomonas aeruginosa. J Bacteriol 179: 3127-3132.

Pierson, L.S., III. (2000) Expanding the club: engineering plants to talk to bacteria. Trends Plant Sci 5: 89-91.

Qin, Y., Luo, Z.Q., Smyth, A.J., Gao, P., von Bodman, B.S., and Farrand, S.K. (2000) Quorum-sensing signal binding results in dimerization of TraR and its release from membranes into the cytoplasm. EMBO J 19: 5212-5221.

Reeves, P.R., Hobbs, M., Valvano, M.A., Skurnik, M., Whitfield, C.D.C., Nobuo, K., et al. (1996) Bacterial polysaccharide synthesis and gene nomenclature. Trends Microbiol 4: 495-503.

Reverchon, S., Bouillant, M.L., Salmond, G.P.C., and Nasser, W. (1998) Integration of the quorum-sensing system in the regulatory networks controlling virulence factor synthesis in Erwinia chrysanthemi. Mol Microbiol 29: 14071418.

Rich, R.L., and Myszka, D.G. (2001) BIACORE: a new platform for routine biomolecular interaction analysis. $J \mathrm{Mol}$ Recognit 14: 223-228.
Riggs, P. (2000) Expression and purification of recombinant proteins by fusion to maltose-binding protein. Mol Biotechnol 15: 51-63.

Sambrook, J., Fritsch, E.F., and Maniatis, T. (1989) Molecular Cloning: a Laboratory. Manual, 2nd edn. Cold Spring Harbor, NY: Cold Spring Harbor Laboratory Press.

Seed, P.C., Passador, L., and Iglewski, B.H. (1995) Activation of the Pseudomonas aeruginosa lasl gene by LasR and the Pseudomonas autoinducer PAI: an autoinduction regulatory hierarchy. J Bacteriol 177: 654-659.

Shadel, G.S., and Baldwin, T.O. (1992) Positive autoregulation of the Vibrio fischeri luxR gene. LuxR and autoinducer activate CAMP-catabolite gene activator protein complexindependent and -dependent luxR transcription. J Biol Chem 267: 7696-7702.

Stevens, A.M., and Greenberg, E.P. (1999) Transcriptional activation by LuxR. In Cell-Cell Signaling. Dunny, G.M., and Winans, S.C. (eds). Washington DC: American Society for Microbiology, pp. 231-242.

Tiedeman, A., and Smith, J.M. (1988) LacZY gene fusion cassettes with KanR resistance. Nucleic Acids Res 16: 3587.

Wehland, M., Kiecker, C., Coplin, D.L., Kelm, O., Saenger, W., and Bernhard, F. (1999) Identification of an RcsA/RcsB recognition motif in the promoters of exopolysaccharide biosynthetic operons from Erwinia amylovora and Pantoea stewartii subspecies stewartii. J Biol Chem 274: 33003307.

Welch, M., Todd, D.E., Whitehead, N.A., McGowan, S.J., Bycroft, B.W., and Salmond, G.P.C. (2000) N-acyl homoserine lactone binding to the CarR receptor determines quorum-sensing specificity in Erwinia. EMBO J 19: 631-641.

Whitehead, N.A., Barnard, A.M.L., Slater, H., Simpson, N.J.L., and Salmond, G.P.C. (2001) Quorum-sensing in Gram-negative bacteria. FEMS Microbiol Rev 719: 140.

Whiteley, M., Lee, K.M., and Greenberg, E.P. (1999) Identification of genes controlled by quorum sensing in Pseudo-monas aeruginosa. Proc Natl Acad Sci USA 96: 13904-13909.

Williams, P., Camara, M., Hardman, A., Swift, S., Milton, D., Hope, V.J., et al. (2000) Quorum sensing and the population-dependent control of virulence. Philos Trans $R$ Soc Lond B Biol Sci 355: 667-680.

Withers, H., Swift, S., and Williams, P. (2001) Quorum sensing as an integral component of gene regulatory networks in Gram-negative bacteria. Curr Opin Microbiol 4: 186-193.

Zhu, J., and Winans, S.C. (1999) Autoinducer binding by the quorum-sensing regulator TraR increases affinity for target promoters in vitro and decreases TraR turnover rates in whole cells. Proc Natl Acad Sci USA 96: 4832-4837.

Zhu, J., and Winans, S.C. (2001) The quorum-sensing transcriptional regulator TraR requires its cognate signaling ligand for protein folding, protease resistance, and dimerization. Proc Natl Acad Sci USA 98: 1507-1512. 